\title{
From the Mediterranean to the Libyan Sahara. Chemical analyses of Garamantian glass.
}

\author{
Chloë N. Duckworth, ${ }^{1 \text { a }}$ David J. Mattingly ${ }^{1}$ and Victoria C. Smith ${ }^{2}$ \\ ${ }^{1}$ School of Archaeology and Ancient History, University of Leicester \\ ${ }^{2}$ Research Laboratory for Archaeology and the History of Art, University of Oxford \\ ${ }^{a}$ Corresponding author. Email: cd227@le.ac.uk. Address: School of Archaeology and \\ Ancient History, University of Leicester, University Road, Leicester LE2 1YH, UK. \\ Telephone: 01162525735.
}

This paper presents the results of electron microprobe analysis of 124 samples of glass from sites in Libya, most from the Saharan oasis belt of the Wadi al-Ajal. Imported Roman vessel glass; beads; vitreous production waste; and Islamic glass bangles have all been analysed, and provide the first chemical information on glass from this region.

Key Words: Fazzan; Roman glass; EPMA; Garamantes; glass bangles; glass beads; Ghirza; Sahara; Libya

\section{Introduction and Background}

The central Saharan region of Fazzan (see Figure 1) is of particular significance for debate about patterns of historic Saharan trade because of the recognition of the existence here of an early oasis farming civilisation, known as the Garamantes (Mattingly 2003; 2013a). There is impressive evidence now available for a significant level of trade with the Mediterranean lands in pre-Islamic times. This work is necessitating a re-evaluation of the connectedness of the Sahara with the Mediterranean and also with Sub-Saharan lands. Compositional analysis of artefacts found at sites in Fazzan, from the final centuries BC to the second millennium $\mathrm{AD}$, has an important part to play in fleshing out our knowledge and understanding of these contacts, as well as potentially illuminating key questions of technological transfer across the Sahara. This paper presents the results of electron microprobe analysis (EPMA) conducted on 124 samples of glass as part of an ongoing programme of chemical analysis also including non-destructive $\mu \mathrm{XRF}$, trace element and isotope analyses.

Over 3500 fragments of glass have been recovered from excavations and survey directed by a number of individuals who worked in the area at different times: Mohammed Ayoub, 1961 to 1969; Charles Daniels, 1958 to 1977 (see Mattingly 2010); and David Mattingly, with the Fazzan Project, 1997-2001 (Mattingly 2007, 2013a) and Desert Migrations Project, 20072011. Glasses were also recovered by the Italian-led excavations of the 1930s (see Pace et al. 1951).

Roman vessel glasses were almost certainly imported directly to Fazzan, but other glasses, including 15 Indo-Pacific beads, may have arrived via a more 'down-the-line' model. Cemetery sites have yielded glass beads in contexts dating to as early as the $5^{\text {th }}$ century $\mathrm{BC}$, as well as Hellenistic and Early Roman cast glass vessels. The importation of glass seems to have reached a peak between the $1^{\text {st }}$ and $4^{\text {th }}$ centuries $\mathrm{AD}$, but it continued throughout the first millennium and beyond; shifts in the focus of trade routes coupled with changing burial practices under Islam probably account for the smaller volume of vessels from the later periods, but glass beads and bangles testify to the continued importation and use of glass throughout the second millennium. 


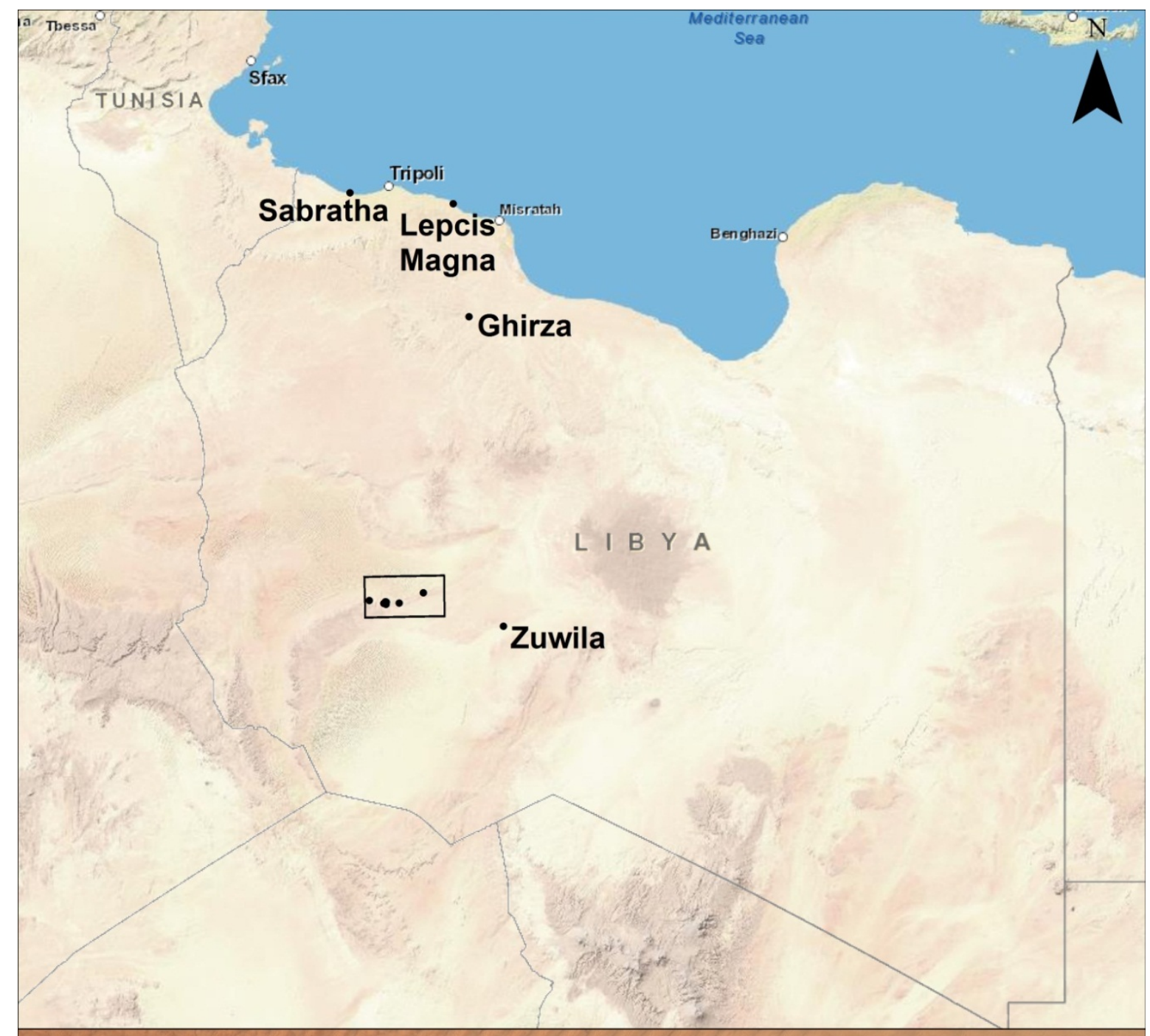

Wadi al-Ajal

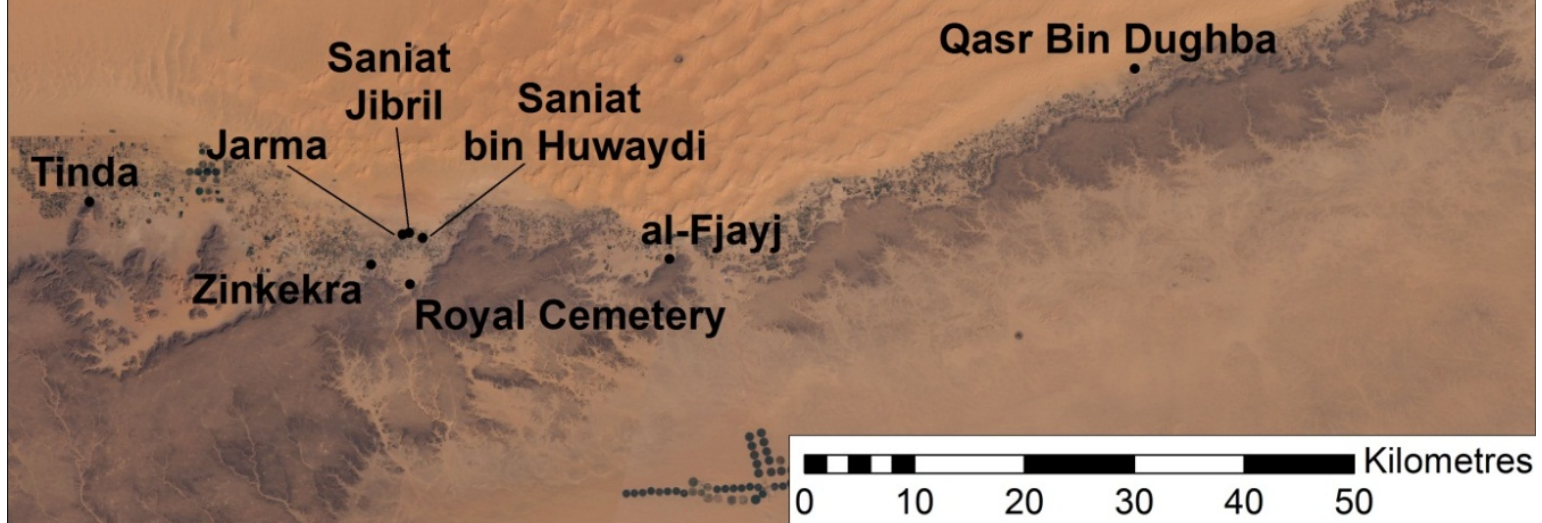

Figure 1. Map of Libyan sites mentioned in the text. Imagery (C) ESRI. (M. Sterry).

Most chemical analyses of North and West African glasses have focused on Islamic material, as the evidence for pre-Islamic glass is incredibly scarce. A major aim has been to determine the provenance of glasses, especially beads (e.g. Brill 1994; Dussubieux 2010; Robertshaw et 
al. 2010, 2014), with a view to reconstructing trade routes. Vessel glass is more rarely encountered, but by the $9^{\text {th }}$ and $10^{\text {th }}$ centuries was certainly heading south along the West African gold trade routes (Insoll 1996, 63-7; Insoll 1998; McIntosh 1995, 247). The extent to which glass was made or recycled in areas linked by, or to trans-Saharan trade routes remains unclear. The currently available evidence does not pre-date the Islamic period and is mainly concentrated in West Africa (e.g. Cissé 2010, 206-15; Robertshaw et al. 2010; Freestone 2006; Lankton et al. 2006).

\section{Materials and Methods}

Due to the political situation in Libya, material from the most recent excavations is currently unavailable for analysis. The work reported here was conducted on 124 samples of glass, most brought to the UK by Charles Daniels, and currently stored at the University of Leicester. The details of the sampled material are summarised in Table 1. Jarma was an urban site, the Garamantian capital until the $7^{\text {th }}$ century $\mathrm{AD}$, but also with a post-Garamantian afterlife to the $20^{\text {th }}$ century (Mattingly 2013a). Most of the glass found at this site is Roman or Late Roman in date, though there are some later Islamic bangles. Qasr bin Dughba is a large fortified Garamantian site, mainly Late Roman in date (Mattingly 2007). The Royal Cemetery, close to Jarma, is the probable burial ground of Late Garamantian (AD 400-700) rulers, whereas Saniat bin Huwaydi is primarily a Classic Garamantian (AD 1-400) cemetery of less high status, but still featuring numerous glass imports (Mattingly 2010). Saniat Jibril was a secondary Garamantian centre, essentially a village, close to and contemporary with Jarma. It had a significant productive component and one explanation for extensive finds of glass here could be that it was collected as cullet for recycling (Mattingly 2010). Tinda and Zinkekra were earlier occupation sites of the Garamantes, receiving glass imports from the second half of the $1^{\text {st }}$ millennium BC and the latter continued in use for Classic Garamantian cemeteries (Mattingly 2010). Finally, glass from Zuwila, about $300 \mathrm{~km}$ east of Jarma relates to a Garamantian cemetery, but may include Islamic era material (Mattingly 2007).

\begin{tabular}{|c|c|c|c|c|}
\hline Site & $\begin{array}{l}\frac{n}{0} \\
0 \\
0 \\
0 \\
0\end{array}$ & $\underset{\varpi}{\tilde{\Xi}}$ & 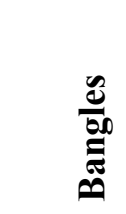 & 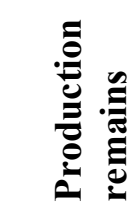 \\
\hline al-Fjayj cemetery & 1 & & & \\
\hline Jarma urban settlement & & 4 & 13 & 10 \\
\hline Qasr Bin Dughba urban settlement & 7 & & & \\
\hline Royal Cemetery & 5 & & & \\
\hline Saniat bin Huwaydi cemetery & 13 & & 3 & \\
\hline Saniat Jibril settlement / productive quarter & 13 & & 9 & \\
\hline Tinda escarpment settlement & 3 & & & \\
\hline Zinkekra cemetery and settlement & 8 & 3 & 3 & \\
\hline Zuwila cemetery & 1 & 12 & & \\
\hline
\end{tabular}

Table 1. Garamantian sites from which material was obtained for sampling. Two bangles were excluded as their find spot is unknown. Two samples of vessel glass from Sabratha, and twelve from Ghirza were also analysed.

Glass from two North Libyan sites was also analysed for comparison. Sabratha was a large Punic and Roman coastal harbour city, open to Mediterranean trade, while Ghirza was a large village in the pre-desert zone between Sabratha and Fazzan, with evidence of late Roman and Islamic trade. 
Electron microprobe analysis (EPMA) was conducted at the Research Laboratory for Archaeology and the History of Art, University of Oxford. The full tables of EPMA results are to be published along with the results of LA-ICP-MS (Duckworth et al. forthcoming). The glasses were analysed on a JEOL-8600 wavelength-dispersive electron microprobe with $15 \mathrm{kV}$ accelerating voltage, $7 \mathrm{nA}$ current, and $10 \mu \mathrm{m}$ diameter beam. Peak counting times were 20s for $\mathrm{Ca}$ and $\mathrm{K}$; 30s for $\mathrm{Si}, \mathrm{Al}, \mathrm{Mg}$; 40s for Fe; 50 s for $\mathrm{Cl}, \mathrm{Mn}$ and $\mathrm{Pb}$; 60s for $\mathrm{Sn}$ and $\mathrm{Sb}$; and $80 \mathrm{~s}$ for $\mathrm{P}$ and $\mathrm{Cu}$. The microprobe was calibrated using a suite of mineral standards, and quantified using the PAP absorption correction method. The accuracy of the electron microprobe analyses was assessed using Corning reference glasses. The values for the Corning glasses are reported in Table 3 , which are very similar to the preferred values (see Vicenzi et al., 2002). The results presented are the average of three spot analyses. The laser ablation-inductively coupled plasma mass spectrometry (LA-ICP-MS) was conducted in the Centre for Environmental Geochemistry, British Geological Survey, Keyworth. The instrument consists of a NewWave FX 193nm excimer laser with integral microscope and ablation cell coupled to an Agilent 7500c series ICP-MS using a He gas flow. The instrument was calibrated using SRM610 glass (NIST, USA), and quality was assessed using SRM612 and Corning glass.

Reduced compositions (where used) were obtained by removing oxides principally associated with added colorants and normalising the remaining seven oxides $\left(\mathrm{Na}_{2} \mathrm{O}, \mathrm{MgO}, \mathrm{Al}_{2} \mathrm{O}_{3}, \mathrm{SiO}_{2}\right.$, $\mathrm{K}_{2} \mathrm{O}, \mathrm{CaO}$ and $\mathrm{Fe}_{2} \mathrm{O}_{3}$ ) to $100 \%$.

\section{Results and Discussion}

\subsection{Vessel Glass}

Due to its fragility, vessel glass is perhaps an unlikely commodity for long-distance overland trade. But it is clear that the Garamantes were importing large quantities of it: 2174 fragments, from a minimum of 350 vessels, have been recovered to date, and the excavation and survey work conducted has only scratched the surface of the vast area occupied.

Many of the vessel glasses sampled for analysis were from more or less intact Hellenistic and Roman vessels recovered from tombs, and can be well dated by a combination of typology and archaeological context. All were found to be relatively low in $\mathrm{MgO}$ and $\mathrm{K}_{2} \mathrm{O}$, and high in $\mathrm{Cl}$, consistent with glass produced using a mineral alkali such as natron. Six suggested compositional groupings are summarised in Table 2.

\begin{tabular}{|c|c|c|c|c|c|c|c|c|c|c|c|}
\hline & $\mathrm{Na}_{2} \mathrm{O}$ & MgO & $\mathrm{Al}_{2} \mathrm{O}_{3}$ & $\mathrm{SiO}_{2}$ & $\mathrm{Cl}$ & $\mathrm{K}_{2} \mathrm{O}$ & $\mathrm{CaO}$ & $\mathrm{TiO}_{2}$ & MnO & $\mathrm{Fe}_{2} \mathrm{O}_{3}$ & $\mathrm{Sb}_{2} \mathrm{O}_{5}$ \\
\hline $\begin{array}{l}\text { Sb decoloured } \\
A(n=23)\end{array}$ & 19.28 & 0.49 & 1.74 & 69.09 & 1.61 & 0.45 & 6.02 & 0.07 & 0.02 & 0.39 & 0.83 \\
\hline s.d. & 0.96 & 0.13 & 0.13 & 1.47 & 0.17 & 0.09 & 0.75 & 0.01 & 0.01 & 0.08 & 0.29 \\
\hline $\begin{array}{l}\text { Sb decoloured } \\
B(n=6)\end{array}$ & 18.93 & 0.67 & 2.00 & 67.61 & 1.39 & 0.68 & 6.26 & 0.11 & 0.35 & 0.61 & 0.76 \\
\hline s.d. & 1.12 & 0.11 & 0.16 & 1.86 & 0.07 & 0.09 & 0.78 & 0.02 & 0.16 & 0.13 & 0.27 \\
\hline $\begin{array}{l}\text { Intermediate } \\
M n(n=5)\end{array}$ & 19.85 & 0.74 & 1.74 & 67.63 & 1.53 & 0.49 & 6.57 & 0.09 & 0.71 & 0.61 & 0.13 \\
\hline s.d. & 1.28 & 0.25 & 0.22 & 2.08 & 0.27 & 0.14 & 0.47 & 0.02 & 0.17 & 0.27 & 0.09 \\
\hline $\begin{array}{l}\text { Mn- } \\
\text { decoloured } \\
(n=12)\end{array}$ & 19.59 & 0.89 & 2.00 & 66.33 & 1.26 & 0.51 & 7.26 & 0.12 & 1.39 & 0.59 & 0.02 \\
\hline s.d. & 0.92 & 0.19 & 0.17 & 1.91 & 0.24 & 0.13 & 0.97 & 0.03 & 0.36 & 0.15 & 0.01 \\
\hline Aqua $(n=5)$ & 15.62 & 0.55 & 2.54 & 70.17 & 1.39 & 0.61 & 8.14 & 0.06 & 0.74 & 0.35 & 0.02 \\
\hline s.d. & 0.66 & 0.06 & 0.24 & 0.61 & 0.08 & 0.08 & 0.58 & 0.01 & 0.38 & 0.04 & 0.02 \\
\hline
\end{tabular}




\begin{tabular}{|r|rrrrrrrrrrr|}
\cline { 2 - 5 }$(\mathrm{n}=12)$ & 19.62 & 1.08 & 2.45 & 65.90 & 1.53 & 0.39 & 5.56 & 0.36 & 2.01 & 1.39 & 0.02 \\
s.d. & 1.28 & 0.18 & 0.24 & 2.37 & 0.21 & 0.05 & 0.75 & 0.13 & 0.27 & 0.81 & 0.01 \\
\hline
\end{tabular}

Table 2. Average compositions (wt.\%) of the six major sub-divisions in the vessel glass. s.d. $=1$ standard deviation. Data for $\mathrm{TiO}_{2}$ calculated from preliminary LA-ICP-MS results.

Five aqua-coloured glasses are distinguished by lower $\mathrm{Na}_{2} \mathrm{O}$, higher $\mathrm{SiO}_{2}$ and higher $\mathrm{CaO}$. Three of them, shown in Figure 2, were fragments of $1^{\text {st }}$ century AD pillar-moulded bowls, and are compositionally very similar to one another. Hoffmann et al. $(2010,414)$ observe that certain categories of glass vessel from Fazzan have unusual size ranges: excessive in some cases (e.g. cast plates $<380 \mathrm{~mm}$ in diameter); and relatively restricted in others (including the pillar-moulded bowls, of which 9 out of 13 measurable diameters are between 114 and $127 \mathrm{~mm}$ ). Restriction in size and composition may suggest that - for at least some of the vessel glasses - the channels by which they reached Fazzan were somewhat limited, by comparison with the interwoven networks of trade and exchange in the Mediterranean.
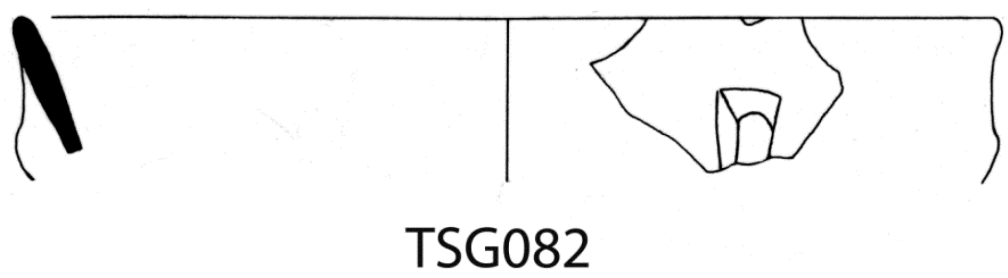

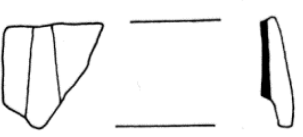

TSG083

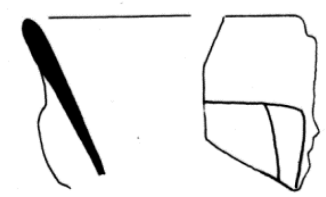

TSG084

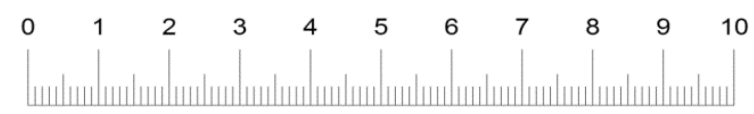

Figure 2. The three fragments of pillar-moulded bowls analysed by EPMA. All were recovered from surface collection survey in Saniat Jibril. Illustrations by Miriam Daniels.

Another group is comprised of glasses which all date to between the $4^{\text {th }}$ and $5^{\text {th }}$ centuries AD, and which have compositional features consistent with the so-called 'HIMT' glass composition, thought to have been produced in Egypt and recognised by a positive correlation between $\mathrm{Fe}_{2} \mathrm{O}_{3}$ and $\mathrm{Al}_{2} \mathrm{O}_{3}$, a weak positive correlation between $\mathrm{Fe}_{2} \mathrm{O}_{3}$ and $\mathrm{MnO}$, relatively high $\mathrm{Na}_{2} \mathrm{O}$ and $\mathrm{MgO}$, and relatively low $\mathrm{CaO}$ (Freestone 1994; Freestone et al. 2005; Foster and Jackson 2009).

The remaining glasses can be broadly distinguished on the basis of the choice of decolourant. Antimony ( $\mathrm{Sb}$ ), which had been the main decolourant for Hellenistic and Early Roman glass, was replaced by manganese $(\mathrm{Mn})$ in the $2^{\text {nd }}$ century AD (Davison 2003, 78). The securely dated glasses from Fazzan and Ghirza follow this general pattern, with just one exception: a shell-shaped fragment from a $4^{\text {th }}$ century AD conchylia cup (reported in Tagart 1982) was found to contain $0.60 \% \mathrm{Sb}_{2} \mathrm{O}_{3}$ and just $0.01 \% \mathrm{MnO}$. 
The assignation of the glasses into compositional groups follows a long trend in the literature, and is certainly helpful in defining the variation within an assemblage. But it is increasingly apparent that compositional distinctions are not always clear-cut. Of the glasses discussed here, there are two 'groups' which are compositionally less clearly definable. The 'Sbdecoloured B' group is made up of glasses which were decoloured by $\mathrm{Sb}$, but which also have slightly elevated $\mathrm{Mn}$. The glasses decoloured by $\mathrm{Mn}$ show more variation, with the group dubbed 'Intermediate $\mathrm{Mn}$ ' having somewhat higher $\mathrm{Sb}_{2} \mathrm{O}_{5}$ than the 'Mn-decoloured' group. Several of the Mn-decoloured glasses are compositionally consistent with the "weak HIMT' group defined by Rosenow and Rehren (2014), but in our case they do not form a tight group and may be the result of mixing glasses of different compositions.

\subsection{Beads}

Over 3400 beads made of a range of materials have been recovered from Fazzan. Many were found in burial contexts. Beads of all materials attest to long-distance trade, and include IndoPacific 'trade wind' beads, and beads made with lapis lazuli from Afghanistan or carnelian from elsewhere in the Sahara (on Garamantian working of Saharan carnelian, see Gliozzo et al. 2014).

Of those glass beads available for analysis, eleven complete beads were analysed by nondestructive $\mu \mathrm{XRF}$ only: the results are reported in Duckworth et al. (in press). The remaining eight beads, all from surface collection survey or unstratified contexts, were analysed by EPMA, and are commented upon here. As can be seen in Figure 3, those from Jarma (top row) are all wound beads, and have suffered surface alteration through corrosion. The beads from Zuwila (bottom row) are all greenish or aqua in colour, and in common with the beads analysed by $\mu \mathrm{XRF}$, they have indications of malformation (such as closed or nearly-closed threadholes) and low-temperature mixing (such as streaks of different colours).
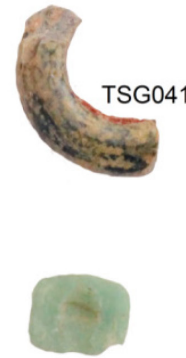

TSG051
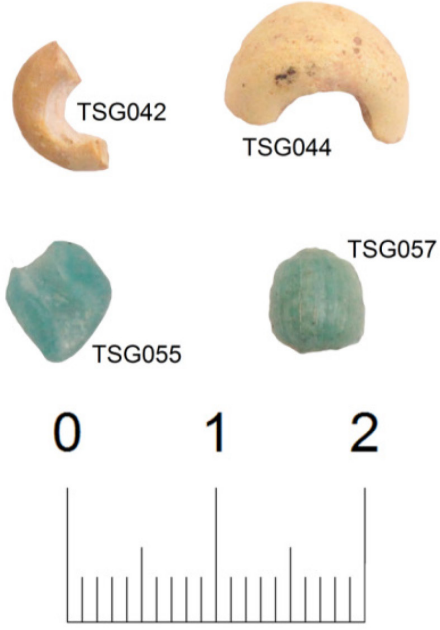

Figure 3. Fragmented beads analysed by EPMA. Original colours of corroded beads (top row): blue (TSG041), opaque yellow (TSG042, TSG044) and green (TSG045).

As shown in Table 3, all eight of the beads, whether from Jarma or Zuwila, are compositionally consistent with the use of a mineral alkali source, as discussed above. The aqua/greenish colour of the Zuwila beads probably results from their $\mathrm{Fe}_{2} \mathrm{O}_{3}$ and $\mathrm{CuO}$ contents, which are higher than those of most of the vessel glasses. The range for most other oxides falls within that of the vessel glasses (excluding the very high lead glass, TSG044), except that the $\mathrm{CaO}$ is on average lower in the beads. 


\begin{tabular}{|c|c|c|c|c|c|c|c|c|c|}
\hline & Label & $\mathrm{Na}_{2} \mathrm{O}$ & $\mathrm{MgO}$ & $\mathrm{Al}_{2} \mathrm{O}_{3}$ & $\mathrm{SiO}_{2}$ & $\mathrm{P}_{2} \mathrm{O}_{5}$ & $\mathrm{Cl}$ & $\mathrm{K}_{2} \mathrm{O}$ & $\mathrm{CaO}$ \\
\hline \multirow{4}{*}{ Jarma } & TSG041 & 12.73 & 0.87 & 2.5 & 72.59 & 0.1 & 0.97 & 1.03 & 8.54 \\
\hline & TSG042 & 18.65 & 0.94 & 1.58 & 72.69 & 0.03 & 2.02 & 0.13 & 4.49 \\
\hline & TSG044 & 6.39 & 0.13 & 1.17 & 47.39 & 0.03 & 0.33 & 0.35 & 4.3 \\
\hline & TSG045 & 15.25 & 0.57 & 1.49 & 68.06 & 0.11 & 1.1 & 0.74 & 8.99 \\
\hline \multirow{4}{*}{ Zuwila } & TSG051 & 20.62 & 0.53 & 2.06 & 62.58 & 0.09 & 1.69 & 0.43 & 4.37 \\
\hline & TSG055 & 20.89 & 0.5 & 2.35 & 66.89 & 0.09 & 1.55 & 0.39 & 3.78 \\
\hline & TSG057 & 19.41 & 0.67 & 2.65 & 66.68 & 0.1 & 1.64 & 0.46 & 2.78 \\
\hline & TSG058 & 20.73 & 0.49 & 2.34 & 66.98 & 0.07 & 1.54 & 0.39 & 3.76 \\
\hline \multirow{2}{*}{$\begin{array}{c}\text { Corning } \\
A\end{array}$} & avg. $(n=6)$ & 14.23 & 2.74 & 0.86 & 66.85 & 0.12 & 0.12 & 2.90 & 5.13 \\
\hline & $1 \mathrm{std}$. dev. & 0.34 & 0.05 & 0.04 & 0.39 & 0.02 & 0.02 & 0.02 & 0.07 \\
\hline \multirow{2}{*}{$\begin{array}{c}\text { Corning } \\
B\end{array}$} & avg. $(n=9)$ & 16.96 & 1.08 & 4.19 & 61.78 & 0.83 & 0.23 & 1.05 & 8.84 \\
\hline & $1 \mathrm{std}$. dev. & 0.17 & 0.02 & 0.04 & 0.40 & 0.02 & 0.01 & 0.03 & 0.10 \\
\hline & & MnO & $\mathrm{Fe}_{2} \mathrm{O}_{3}$ & $\mathrm{CuO}$ & $\mathrm{SnO}_{2}$ & $\mathrm{Sb}_{2} \mathrm{O}_{5}$ & $\mathrm{PbO}$ & Total & \\
\hline \multirow{4}{*}{ Jarma } & TSG041 & 0.08 & 0.72 & 0.18 & 0.01 & 0.03 & 0.02 & 100.36 & \\
\hline & TSG042 & 0.02 & 0.8 & 0.01 & 0.01 & 0 & 0.05 & 101.41 & \\
\hline & TSG044 & 0.02 & 2.72 & 0.04 & 0 & 3.02 & 32.5 & 98.38 & \\
\hline & TSG045 & 0.03 & 0.97 & 3.14 & 0.05 & 0.05 & 0.12 & 100.69 & \\
\hline \multirow{4}{*}{ Zuwila } & TSG051 & 0.02 & 0.93 & 0.94 & 0.42 & 0.03 & 4.91 & 99.6 & \\
\hline & TSG055 & 0.01 & 1.11 & 0.96 & 0.08 & 0.03 & 1.17 & 99.8 & \\
\hline & TSG057 & 0.05 & 1.04 & 1.5 & 0.28 & 0.02 & 2.52 & 99.81 & \\
\hline & TSG058 & 0 & 1.08 & 1.18 & 0.08 & 0.02 & 0.93 & 99.6 & \\
\hline \multirow{2}{*}{$\begin{array}{c}\text { Corning } \\
\text { A }\end{array}$} & avg. $(n=6)$ & 1.04 & 0.99 & 1.26 & 0.22 & 1.97 & 0.13 & 98.56 & \\
\hline & $1 \mathrm{std}$. dev. & 0.06 & 0.13 & 0.05 & 0.03 & 0.05 & 0.17 & 0.69 & \\
\hline Corning & avg. $(n=9)$ & 0.24 & 0.30 & 2.92 & 0.06 & 0.49 & 0.55 & 99.58 & \\
\hline$B$ & $1 \mathrm{std}$. dev. & 0.04 & 0.06 & 0.06 & 0.02 & 0.05 & 0.18 & 0.67 & \\
\hline
\end{tabular}

Table 3. Composition (wt.\%) of the eight beads from Jarma and Zuwila analysed by EPMA.

One bead each from Zuwila (TSG051) and Jarma (TSG044) were found to have been coloured and opacified by lead: lead-antimonate in TSG044, a yellow opaque bead with $32.50 \% \mathrm{PbO}$ and $3.02 \% \mathrm{Sb}_{2} \mathrm{O}_{5}$; and lead-tin opacifiers in TSG051, a green bead with $4.91 \%$ $\mathrm{PbO}$ and $0.42 \% \mathrm{SnO}_{2}$. As demonstrated by Tite et al. (2008), lead-tin based opacifiers (lead stannate) were first used in Europe from the second to first centuries BC, and then again throughout the Roman and Byzantine Empires from the fourth century AD onwards. The bead from Jarma opacified by lead antimonite might thus be dated to between the first and fourth century $\mathrm{AD}$, whereas that from Zuwila is more likely to be a Late Roman or Byzantine import, though it should be noted that lead stannate was also used in Islamic ceramic glazes. It should also be noted, however, that in both cases the lead was excessively high for the purpose of colouring.

Three possibilities are put forward for the origin of these beads, that they were: i) traded from the Mediterranean or Egypt; ii) made by recycling Roman glasses; iii) produced using locally available raw ingredients (on the latter, see the discussion below). As they were made with a mineral alkali, it is likely that the beads date to the Classic or Late Garamantian periods (AD 
1-700), but there are other possibilities. For example, recycling of Roman glasses could have taken place at any date after the Classic Garamantian phase. Similarly, production using a local mineral source would not necessarily have ceased at the time that Mediterranean glass production shifted to the use of plant ashes $\left(8^{\text {th }}-9^{\text {th }}\right.$ centuries AD).

\subsection{Unidentified Vitreous Remains}

Among the finds from Fazzan were a number of fragments of waste material which are of interest as they may be the remains of glass production, either primary (glass making) or secondary (re-melting or recycling); one of these is shown in Figure 4. Eighteen such fragments were recovered in total, all from Jarma. The ten available for analysis came from Building 1, from a Classic Garamantian (AD 1-400) pit filled with ash and 'mortar lumps' and cut into by a hearth feature. Three of these were largely crystalline and high in $\mathrm{SiO}_{2}$, and are omitted from discussion. A further eight examples of unidentified vitreous remains, including splashes of glass adhering to local handmade pottery, were uncovered by the Fazzan Project, all but one from contexts of various dates between 50 and 850 AD.

As shown in Table 4, two samples (TSG144 and TSG145) of the vitreous waste analysed have low $\mathrm{MgO}$, compatible with the use of a mineral alkali, but the $\mathrm{K}_{2} \mathrm{O}$ content is much higher than typically encountered in Roman glasses. The remaining glasses have higher $\mathrm{MgO}$ which may indicate the use of plant ash alkali, but the $\mathrm{K}_{2} \mathrm{O}: \mathrm{MgO}$ ratio for these is nonetheless unusually high.

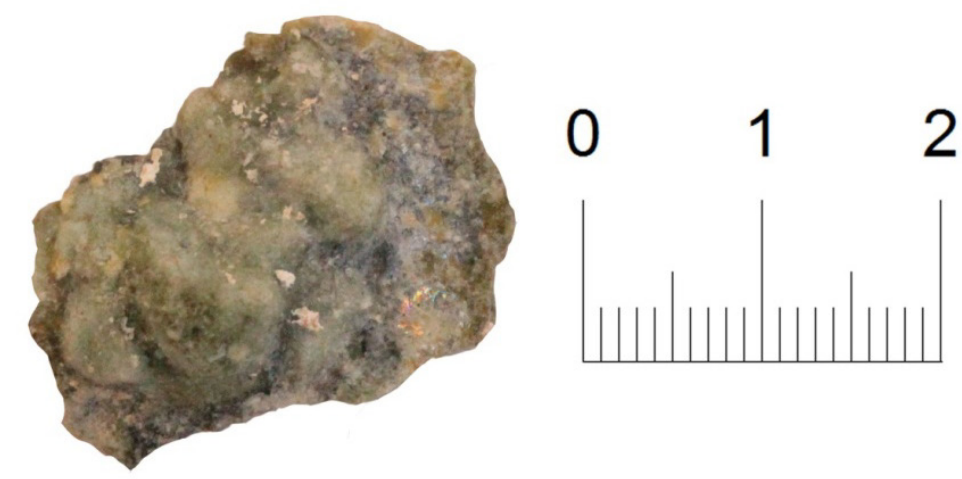

Figure 4. Fragment of vitreous production waste TSG150. Vitreous phase with crystalline inclusions adhering to buff-coloured ceramic. Thickness of vitreous phase: $<5 \mathrm{~mm}$. Excavated at Jarma. Scale in cm.

In most ancient soda glasses, any $\mathrm{K}_{2} \mathrm{O}$ present was brought in with the $\mathrm{Na}_{2} \mathrm{O}$. There are deposits of alkali minerals just north of the Wadi al-Ajal, notably Lake Trona in the Ubari sand sea. Four samples from Lake Trona were analysed by ICP-OES by Fabri $(2013,14)$ and the $\mathrm{K}$ content was found to vary widely, from $1700 \mathrm{ppm}$ to $69,000 \mathrm{ppm}$ (equivalent to $0.2-$ $8.31 \% \mathrm{~K}_{2} \mathrm{O}$ ). Recent work on B isotopes by Devulder et al. (2014) has shown that Fazzan could have been a source of alkali minerals for Roman glass production, but was unable to conclusively demonstrate this, as there is a degree of overlap with the Egyptian sources. On the other hand, it seems that at least some of the $\mathrm{K}_{2} \mathrm{O}$ in these vitreous remains may have been brought in with the sand: a weak negative correlation was observed between $\mathrm{K}_{2} \mathrm{O}$ and $\mathrm{Na}_{2} \mathrm{O}$, and between $\mathrm{K}_{2} \mathrm{O}$ and $\mathrm{MgO}$; as well as a weak positive correlation between $\mathrm{K}_{2} \mathrm{O}$ and $\mathrm{SiO}_{2}$.

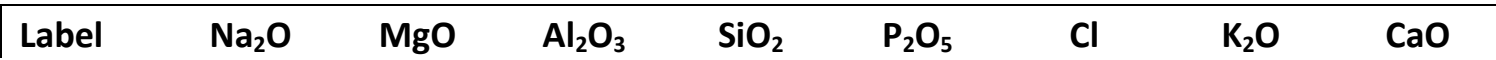




\begin{tabular}{|c|c|c|c|c|c|c|c|c|}
\hline TSG144 & 12.86 & 0.53 & 5.20 & 73.51 & 0.04 & 0.38 & 5.46 & 1.70 \\
\hline TSG145 & 10.15 & 0.99 & 5.18 & 74.12 & 0.07 & 0.27 & 5.56 & 2.14 \\
\hline TSG146 & 14.26 & 2.92 & 6.59 & 63.30 & 0.26 & 0.07 & 3.80 & 5.65 \\
\hline TSG147 & 12.12 & 2.25 & 9.05 & 65.29 & 0.13 & 0.08 & 4.07 & 3.90 \\
\hline TSG148 & 10.43 & 1.37 & 8.63 & 68.82 & 0.14 & 0.03 & 5.30 & 1.15 \\
\hline TSG149 & 12.35 & 2.71 & 5.94 & 65.70 & 0.18 & 0.06 & 4.68 & 4.59 \\
\hline \multirow[t]{2}{*}{ TSG150 } & 10.30 & 1.74 & 5.32 & 69.60 & 0.13 & 0.29 & 4.37 & 6.37 \\
\hline & $\mathrm{MnO}$ & $\mathrm{Fe}_{2} \mathrm{O}_{3}$ & $\mathrm{CuO}$ & $\mathrm{SnO}_{2}$ & $\mathrm{Sb}_{2} \mathrm{O}_{5}$ & $\mathrm{PbO}$ & Total & \\
\hline TSG144 & 0.08 & 0.91 & 0.02 & 0.00 & 0.18 & 0.00 & 100.86 & \\
\hline TSG145 & 0.07 & 1.82 & 0.00 & 0.01 & 0.19 & 0.05 & 100.63 & \\
\hline TSG146 & 0.10 & 2.67 & 0.01 & 0.01 & 0.11 & 0.03 & 99.78 & \\
\hline TSG147 & 0.04 & 3.63 & 0.00 & 0.00 & 0.15 & 0.02 & 100.72 & \\
\hline TSG148 & 0.01 & 3.87 & 0.00 & 0.00 & 0.14 & 0.05 & 99.93 & \\
\hline TSG149 & 0.03 & 2.81 & 0.00 & 0.04 & 0.13 & 0.02 & 99.24 & \\
\hline TSG150 & 0.04 & 1.94 & 0.01 & 0.00 & 0.12 & 0.01 & 100.26 & \\
\hline
\end{tabular}

The vitreous remains are also high in $\mathrm{Fe}_{2} \mathrm{O}_{3}$ and especially in $\mathrm{Al}_{2} \mathrm{O}_{3}$. Sands in the vicinity of Jarma have been observed to be fairly mature, quartzitic sands with a modest grain coating of amorphous iron oxides and silicates (Kevin White, pers. comm.), which could explain the iron and aluminium content. The vitreous remains are also low in $\mathrm{CaO}$, which could suggest the use of a mineral alkali coupled with an inland sand source. Low $\mathrm{CaO}$ glasses are susceptible to disintegration, and it is worth noting that these remains were located in one of the drier areas excavated: similar materials from other areas may not have survived.

It is important to note that the vitreous remains were probably deliberately discarded, and several adhere to ceramics: they may thus be unrepresentative of the final composition of locally-made or -melted glasses, if indeed these existed. There are some broad compositional similarities between the lower magnesia glasses in this group and mineral-soda-alumina (m$\mathrm{Na}-\mathrm{Al}$ ) glasses (see Dussubieux et al. 2010), but with certain differences (e.g. ratio of $\mathrm{Na}_{2} \mathrm{O}$ to $\mathrm{K}_{2} \mathrm{O}$ ). Beads with m-Na-Al composition are often assigned to an Indian or SE Asian source, but geographically closer possibilities should also be taken into account. For example, Schibille (2011) has identified mineral alkali, high alumina glasses from Pergamon, Anatolia, dating to the eighth-fourteenth centuries AD. Three high alumina, medieval plant ash bead glasses from al-Basra, Morocco have been reported by Robertshaw et al. (2010, 374), although they differ from the glasses reported here in other respects (e.g. quantity and ratio of $\mathrm{MgO}$ and $\mathrm{K}_{2} \mathrm{O}$ ).

\subsection{Bangles}

The bangles analysed, an example of which is shown in Figure 5, were all recovered from surface collection survey. There are few published examples of bangles from stratified contexts anywhere and despite some important typological studies (Monod 1975; Spaer 1992; Boulogne and Hardy-Guilbert 2010) they remain somewhat difficult to date beyond assigning a terminus post quem. The bangles are probably relatively recent in date: although not available for analysis, five examples comparable to those collected from the surface were excavated by the Fazzan Project, all but one from contexts dated to the $18^{\text {th }}$ century or later; the exception is from an Early Islamic (AD 1100-1300) context. 

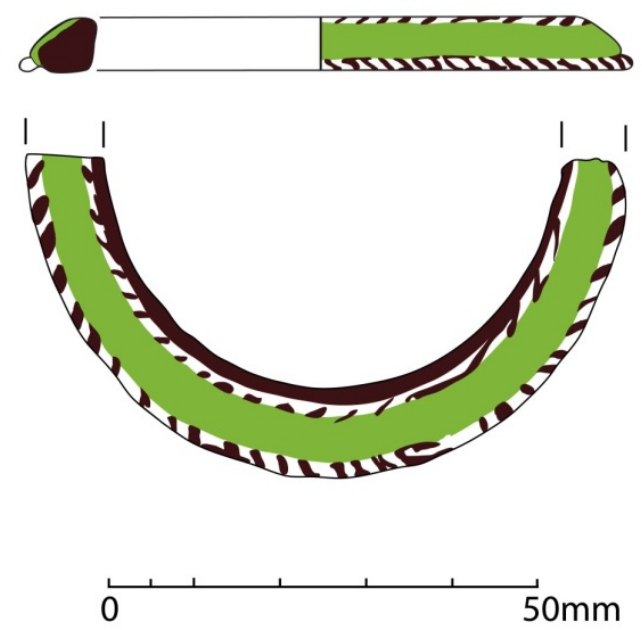

Figure 5. Fragment of a dark brown translucent, opaque green and opaque white bangle (TSG004) with pointed cross-section and applied trails, recovered from surface collection survey at Jarma. Illustration by Michael Hawkes.

Many of the bangles bear indications of low temperature working: numerous air bubbles, streaks of different colours, and non-vitreous inclusions are all visible macroscopically. All are strongly coloured. Hierarchical cluster analysis was performed on the reduced compositional results and was used to construct the groups presented in Table 5. It is possible that bangle glasses were coloured in the workshops in which they were formed, as there is in most cases closer affinity between two colours on the same bangle than between the same colour on two different bangles. The question of relationship between bangles and colorants will be further addressed with a programme of lead isotope analysis, which is currently being conducted with the collaboration of Jane Evans at British Geological Survey, Keyworth.

\begin{tabular}{|c|c|c|c|c|c|c|c|c|}
\hline Group & $\mathrm{Na}_{2} \mathrm{O}^{*}$ & MgO* & $\mathrm{Al}_{2} \mathrm{O}_{3} *$ & $\mathrm{SiO}_{2}{ }^{*}$ & $\mathrm{~K}_{2} \mathrm{O}^{*}$ & CaO* & $\mathrm{Fe}_{2} \mathrm{O}_{3} *$ & Group features \\
\hline $1(n=1 ; 4)$ & 15.53 & 1.04 & 1.25 & 67.70 & 3.12 & 10.63 & 0.75 & \multirow[t]{2}{*}{ Highest Ca } \\
\hline s.d. & 0.29 & 0.11 & 0.13 & 0.65 & 0.17 & 0.22 & 0.11 & \\
\hline $2(n=7 ; 17)$ & 21.55 & 1.01 & 1.43 & 69.34 & 0.65 & 5.38 & 0.63 & \multirow{2}{*}{$\begin{array}{l}\text { Pointed cross-section; dark } \\
\text { base colours ( } \mathrm{MnO})\end{array}$} \\
\hline s.d. & 1.15 & 0.24 & 0.13 & 1.20 & 0.51 & 1.30 & 0.08 & \\
\hline $3(n=7 ; 16)$ & 18.00 & 0.54 & 1.29 & 74.36 & 3.58 & 1.75 & 0.48 & \multirow{2}{*}{$\begin{array}{l}\text { Flat cross-section; translucent } \\
\text { bases }\end{array}$} \\
\hline s.d. & 0.56 & 0.20 & 0.18 & 0.94 & 0.74 & 0.40 & 0.09 & \\
\hline $4(n=6 ; 8)$ & 20.00 & 0.61 & 1.65 & 72.46 & 2.11 & 2.31 & 0.86 & \multirow{2}{*}{$\begin{array}{l}\text { Flat/semi-circular cross- } \\
\text { section; mostly dark } \\
\text { monochrome }\end{array}$} \\
\hline s.d. & 0.95 & 0.13 & 0.44 & 0.88 & 0.81 & 0.79 & 0.35 & \\
\hline $5(n=2 ; 4)$ & 17.75 & 1.22 & 1.29 & 72.65 & 2.45 & 4.13 & 0.51 & \multirow{2}{*}{ Highest MgO } \\
\hline s.d. & 0.46 & 0.17 & 0.10 & 0.90 & 0.24 & 0.34 & 0.09 & \\
\hline $6(n=6 ; 17)$ & 17.54 & 0.90 & 1.54 & 74.05 & 0.15 & 5.00 & 0.83 & \multirow{2}{*}{$\begin{array}{l}\text { Pointed cross-sections; } \\
\text { translucent green bases }\end{array}$} \\
\hline s.d. & 0.71 & 0.11 & 0.28 & 0.78 & 0.04 & 0.88 & 0.20 & \\
\hline
\end{tabular}

Table 5. Average composition (wt.\%) of the six groups of bangles defined on the basis of cluster analysis, along with the key typological and compositional features of each group. The results shown are the reduced compositions, and have been normalised to $100 \%$. $n=$ number of bangles in group; total number of different colours analysed. s.d. = standard deviation. 


\section{Conclusions}

It is clearly apparent that, at least until the Islamic period, the primary source of glass for the Garamantes was the Mediterranean. What was being traded in return for the glasses and other Mediterranean products is a matter of ongoing consideration and debate (Mattingly 2013b; forthcoming). The evidence available to date does not suggest that glass vessels were being traded farther south by the Garamantes: they seem to have kept these items for their own use. But this does not necessarily imply that no Mediterranean glass was finding its way south or west of the Garamantes through Saharan trade routes: we must always bear in mind that recycling and re-working of broken vessel glass could have been taking place, as could the modification of existing beads. Our ongoing analyses will provide more information with which to address these questions.

\section{Acknowledgements}

The research leading to these results has received funding from the European research Council under the European Union's Seventh Framework Programme (FP/2007-2013)/ERC grant agreement number 269418, PI David Mattingly. Many thanks go to Patrick Degryse and Kevin White for providing information on the composition of local alkali minerals and sand.

\section{References}

Boulogne, S. and Hardy-Guilbert, C. 2010. Glass bangles of al-Shihrr, Haḍramawt (fourteenth-nineteenth centuries), a corpus of new data for the understanding of glass bangle manufacture in Yemen. Proceedings of the Seminar for Arabian Studies 40: 135-48.

Brill, R.H. 1994. Chemical analysis of some glasses from Jenné-Jeno. In S. McIntosh (ed.) Excavations at Jenné-Jeno, Hambarketelo, and Kaniana (Inland Nile Delta, Mali), the 1981 Season. Anthropology Vol. 20. Berkely, CA: University of California Press. pp.252-6.

Cissé, M. 2010. Archaeological Investigations of Early Trade and Urbanism at Gao Saney (Mali). Unpublished PhD thesis. Rice University.

Davison, S. 2003. Conservation and Restoration of Glass. Second edition. Oxford: Butterworth Heinemann.

Devulder, V., Vanhaecke, F. Shortland, A. Mattingly, D. Jackson C. and Degryse, P. 2014. Boron isotopic composition as a provenance indicator for the flux raw material in Roman natron glass. Journal of Archaeological Science 46: 107-113.

Duckworth, C.N., Mattingly, D.J., Chenery, S. and Smith, V.C. [forthcoming] Into Africa. Chemical analyses of Roman and Late Antique vessel glass found in the Libyan Sahara.

Duckworth, C.N., Cuénod, A. and Mattingly, D.J. [in press]. Non-destructive $\mu$ XRF analysis of glass and metal objects from sites in the Libyan pre-desert and Fazzan. Libyan Studies 45.

Dussubieux, L. 2010. Appendix III. In M. Cissé Archaeological Investigations of Early Trade and Urbanism at Gao Saney (Mali). Unpublished $\mathrm{PhD}$ thesis. Rice University.

Dussubieux, L., Gratuze, B. and Blet-Lemarquand, M. 2010. Mineral soda alumina glass: occurrence and meaning. Journal of Archaeological Science 37: 1646-55. 
Fabri, M. 2013. Chemische merker voor natron zouten. Unpublished dissertation submitted for Bachelorproef Geologie, KU Leuven.

Foster, H.E. and Jackson, C.M. 2009. The composition of 'naturally coloured' late Roman vessel glass from Britain and the implications for models of glass production and supply. Journal of Archaeological Science 36: 189-204.

Freestone, I.C. 1994. Appendix: chemical analyses of 'raw' glass fragments. In H.R. Hurst (ed.) Excavations at Carthage. The British Mission Volume II, 1. Oxford University Press.

Freestone, I.C. 2006. An indigenous technology? A commentary on Lankton et al. "Early primary glass production in southern Nigeria". Journal of African Archaeology 4 (1): 139-41.

Freestone, I.C., Wolf, S. and Thirlwall, M. 2005. The production of HIMT glass: elemental and isotopic evidence. Annales du $16^{e}$ Congrès de l'Association Internationale pour l'Histoire du Verre.

Gliozzo, E., Mattingly, D. J., Cole, F. and Artioli, G. 2014. In the footsteps of Pliny: tracing the sources of Garamantian carnelian from Fazzan, south-west Libya. Journal of Archaeological Science 52: 218-41.

Henderson, J. 2013. Ancient Glass. An Interdisciplinary Exploration. Cambridge University Press.

Hoffmann, B., Mattingly, D.J., Tagart, C., Cole, F. and Wild, J.P. 2010. Non-ceramic finds from CMD's excavations and the work of M.S. Ayoub. In Mattingly 2010. pp.411-88.

Insoll, T. 1998. Islamic glass from Gao, Mali. Journal of Glass Studies 40: 77-88.

Insoll, T. 1996. Islam, Archaeology and History. Gao Region (Mali), ca. AD 900-1250. Cambridge Monographs in African Archaeology 39. BAR International Series 647. Oxfrod: Archeopress.

Lankton, J.W., Ige, O.A. and Rehren, Th. 2006. Early primary glass production in southern Nigeria. Journal of African Archaeology 4 (1): 111-38.

Mattingly, D.J. (ed.) 2003. The Archaeology of Fazzan. Volume 1. Synthesis. London: Society for Libyan Studies, Department of Antiquities, London.

Mattingly, D.J. (ed.) 2007. The Archaeology of Fazzan. Volume 2. Site Gazetteer, Pottery and other Survey Finds. London: Society for Libyan Studies, Department of Antiquities.

Mattingly, D.J. (ed.) 2010. The Archaeology of Fazzan. Volume 3. Excavations Carried out by C.M. Daniels. London: Society for Libyan Studies, Department of Antiquities.

Mattingly, D.J. (ed.) 2013a. The Archaeology of Fazzan. Volume 4. Survey and Excavations at Old Jarma (Ancient Garama). London: Society for Libyan Studies, Department of Antiquities. 
Mattingly, D.J. 2013b. To south and north: Saharan trade in antiquity. In H. Eckardt and S. Rippon (eds.) Living and Working in the Roman World. Portsmouth (RI): JRA Suppl, 169-90.

Mattingly, D.J. [forthcoming] 2014. Trans-Saharan connectivity and the Garamantes of Southern Libya. In M. Davies and K. MacDonald (eds), Connections, Contributions and Complexity: Africa's Later Holocene Archaeology in Global Perspective. Cambridge.

McIntosh, S. 1995. Stone, glass and bone. In S. McIntosh (ed.) Excavations at Jenné-Jeno, Hambarketelo, and Kaniana (Inland Nile Delta, Mali), the 1981 Season. Anthropology Vol. 20. Berkeley, CA: University of California Press.

Monod, T. 1975. A propos des bracelets de verre sahariens. Bulletin Institut Fondamental d'Afrique Noire 37: 702-18.

Pace, B., Sergi, S. and Caputo, G. 1951. Scavi sahariani. Monumenti Antichi 41: 150-549.

Robertshaw, P., Wood, M., Haour, A., Karklins, K. and Neff, H. 2014. Chemical analysis, chronology and context of a European glass bead assemblage from Garumele, Niger. Journal of Archaeological Science 41: 591-604.

Robertshaw, P., Benco, N., Wood, M., Dussubieux, L., Melchiorre E. and Ettahiri, A. 2010. Chemical analysis of glass beads from Medieval al-Basra (Morocco). Archaeometry 52 (3): 355-79.

Rosenow, D. and Rehren, Th. 2014. Herding cats - Roman to Late Antique glass groups from Bubastis, northern Egypt. Journal of Archaeological Science 49: 170-84.

Schibille, N. 2011. Late Byzantine mineral soda high alumina glasses from Asia Minor: a new primary glass production group. PLoS ONE 6 (4): e18970.

doi:10.1371/journal.pone.0018970

Spaer, M. 1992. Islamic glass bracelets of Palestine: preliminary findings. Journal of Glass Studies 34: 44-62.

Tagart, C. 1982. A glass fish beaker from Fazzan. Libyan Studies 13: 81-4.

Tite, M., Pradell, T. and Shortland, A. 2008. Discovery, production and use of tin-based opacifiers in glasses, enamels and glazes from the Late Iron Age onwards: a reassessment. Archaeometry 50 (1): 67-84.

Vicenzi, E.P., Eggins, S., Logan, A. and Wysoczanski, R. 2002. Microbeam characterization of Corning archeological reference glasses: new additions to the Smithsonian microbeam standard collection. Journal of Research of the National Institute of Standards and Technology 107: 719-728. 